International Journal of Instruction e-ISSN: 1308-1470 • www.e-iji.net

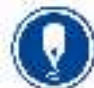

April 2021 • Vol.14, No.2

p-ISSN: 1694-609X

pp. $845-860$

Article submission code

20200131064805

Received: 31/01/2020

Revision: 26/10/2020

Accepted: 19/11/2020

OnlineFirst: 05/03/2021

\title{
RANDAI Learning Model to Enhance Pre-Service Biology Teachers' Critical Thinking Skills
}

\section{Fitri Arsih}

Biology Education Department, Universitas Negeri Padang, Indonesia, fitribio@fmipa.unp.ac.id

\section{Siti Zubaidah}

Prof., Biology Education Program, Universitas Negeri Malang, Indonesia, siti.zubaidah.fmipa@um.ac.id

\section{Hadi Suwono}

Prof., Biology Education Program, Universitas Negeri Malang, Indonesia, hadi.suwono.fmipa@um.ac.id

\section{Abdul Gofur}

Prof., Biology Education Program, Universitas Negeri Malang, Indonesia, abdul.gofur.fmipa@um.ac.id

The current study aimed to investigate the effectiveness of RANDAI learning model that was produced from the integration of Minangkabau culture and Problem Based Learning (PBL), in enhancing pre-service biology teachers' critical thinking skills. This experimental study used a nonequivalent pretest-posttest control group design and involved 107 pre-service biology teachers from Universitas Negeri Padang (State University of Padang), Indonesia. The data were gathered using the critical thinking essay tests. A critical thinking rubric was used to assess the participants' answers, and the results were analyzed using ANCOVA at a significance level of 0.05 . The statistical results showed that RANDAI learning model affected pre-service biology teachers' critical thinking skills. The LSD test result confirmed that there was a significant difference in terms of critical thinking performance between the participants in RANDAI, Problem Based Learning, and conventional classes. Therefore, RANDAI learning model can be used to enhance the pre-service biology teachers' critical thinking skills.

Keywords: design of learning, development of learning, cultural integrated learning, RANDAI, student's critical thinking

\section{INTRODUCTION}

Pre-service biology teachers are the key resources and important agents in science education transformation (Kadir, 2017). Pre-service biology teachers are involved in the

Citation: Arsih, F., Zubaidah, S., Suwono, H., \& Gofur, A. (2021). RANDAI Learning Model to Enhance Pre-Service Biology Teachers' Critical Thinking Skills. International Journal of Instruction, 14(2), 845-860. https://doi.org/10.29333/iji.2021.14247a 
process of nurturing and promoting student interest in biology. Therefore, they are expected to own the knowledge and skills to think critically in facing and understanding the challenges of society changes (Valli \& Buese, 2007). To become a reliable facilitator, training in critical thinking skills needs to be carried out for pre-service biology teachers (Nessipbayeva, 2012), to teach analytical skills, to create changes, to produce learning creativity and innovations (Valli, Perkkilä, \& Valli, 2014) and to master technology and information (Cretu, 2017) to enter the professional world (Suwono et al., 2017). Pre-service teachers must be competent in critical thinking since education basically aims to support the development of students' critical and creative organizing and problem-solving abilities (Serin, 2013).

Critical thinking involves cognitive processes or strategies to solve problems and draw conclusions (Halpern, 1999; Facione, 2011) to be a priority part of universities (Badger, 2019; Al-Mahrooqi \& Denman, 2020) and is necessary for academic success (Alkharusi, Sulaimani \& Neisler, 2019). Zubaidah, et al., (2018) explain critical thinking helps preservice biology teachers become skilled independently in solving problems. Having good critical thinking skills makes pre-service teachers able to investigate assumptions, understand concepts to develop knowledge effectively

Some established facts in the field show that the learning process in higher education in Indonesia has not entirely focused on promoting critical thinking in pre-service teachers (Evens, Verburgh, \& Elen, 2014). Pre-service teachers have not been optimally empowered to think critically (Farcis, 2016) even though it has been recognized that through critical thinking, pre-service teachers are encouraged to discover new ideas and thoughts in solving learning problems as well as to practice analyzing and selecting various opinions. The lack of satisfactory critical thinking skills possessed by preservice biology teachers has been revealed in previous research (Amin et al., 2017), Thus, it is necessary to optimize efforts in empowering their critical thinking skills (Syam \& Efwinda, 2018). Research findings by Fitriani et al., (2019) proved that the pre-service biology teachers from IKIP Mataram had poor critical thinking. A survey Arsih et al., (2020) also provide information that it is necessary to develop critical thinking for pre-service Biology teachers at Padang State University (Arsih, Zubaidah, Suwono, \& Gofur, 2020). Therefore, the improvement of critical thinking skills is paramount in the national education system, especially in biology classrooms (Fuad et al., 2017; Afandi et al., 2019).

Problem Based Learning (PBL) is a learning approach that has the potential to empower critical thinking skills (Zubaidah, 2017). PBL is a student's guide to more meaningful science learning that is relevant to life. PBL has an effect on student critical thinking. Problem-Based Learning (PBL) assumes that problems can be used as a starting point to obtain or integrate new knowledge (Barrett, 2013); therefore, PBL helps students develop their analytical skills on scientific concepts as scientific knowledge and build creativity. (Moutinho, et al. 2015). This learning strategy challenges pre-service teachers to be able to find solutions to a problem (Birgili, 2015). Furthermore, Temel (2014) explains that critical thinking correlates with intelligence, problem solving skills. Anazifa (2016) discovered that PBL had an effect on cognitive achievement and critical thinking. 
However, some of the limitations of PBL in empowering students' critical thinking in science have also been identified (Moutinho et al., 2015; Hidayati et al., 2019). Research has uncovered the weaknesses of Problem-Based Learning (Batdi, 2014; Demirel \& Dagyar, 2016), such as Fitriani et al., (2019), who explained that individual or group PBL activities could not always improve student achievement in biology at all levels of education. Besides, PBL syntax was found to be ineffective in motivating students who lacked preparedness in dealing with psychological pressures. The students' lack of readiness also led to low confidence in organizing and solving problems (Nijhuis, Segers \& Gijselaers, 2005). Therefore, the PBL syntax needs to be modified and adjusted to the learning conditions and situations in Indonesia so that students' motivation and critical thinking can improve accordingly. Proper modifications can include incorporating local culture into education. Cultivating cultural values during the educational process serves as a medium in motivating students to apply the knowledge they have acquired. (Ibe, 2017). The culture-integrated learning can also encourage students' imaginative, metaphorical and creative processes as well as promote students' cultural awareness, performance, and interest in biology (Davison \& Miller, 1998; James 2006: Caballero, 2015)). The integration of local culture into the school curriculum also contributes to the effort of preserving the local Indonesian values that have begun to fade and be abandoned by the students who have a poor understanding of the local culture values (Uge, Neolaka, \& Yasin, 2019).

Cultural values can be incorporated into learning materials or learning models (Anwar, Suardika, T, Suleiman, \& Syukur, 2018), such as Problem-Based Learning. Empirical research explicitly explains the direct effect of the culture-and-art-integrated curriculum on science learning (Hardiman, JohnBull, Carran, \& Shelton, 2019; Suardana et al., 2018; Fadli \& Irwanto, 2020). Findings from Dhanapal, Kanapathy, \& Mastan (2014) indicate that art takes part in individual development. Researchers suggest that the integration of art into science learning at all levels of education can empower students to think critically and develop $21^{\text {st }}$ century skills. Turkka, Haatainen, \& Aksela (2017) conducted a survey on science learning practices and discovered that arts-integrated science education could involve students in creative projects and encourage them to express science in many ways. In short, art-integrated pedagogy can improve students' performance in science.

Randai Minangkabau is one of Indonesia's local art performances that can potentially be integrated into Problem-Based Learning method. Randai traditional arts in the form of pamenan adaik (art game) formulated on the elements of kaba (story) and played by several people in a circle. The stories in Kaba used to be popular in the past. Educational messages from Kaba are conveyed in the form of figurative sentences or cryptic words (Arsih, Zubaidah, Suwono, \& Gofur, 2019). Pedagogically, Randai can serve as a learning medium for Minangkabau people. Some educational values of Randai that can be incorporated into a learning model include barundiang (willing to discuss), bulek kato dek mufakaik, bakarajosamo (cooperative), barani bapandapek (assertive), kaba (story telling), garak malingka (moving in circle) and the dramatic actions kato nan ampek that reflect politeness in speaking (Arsih, Zubaidah, Suwono, \& Gofur, 2019). 
The integration of Randai cultural values into PBL thus generates a learning model called RANDAI (Reciting, Analyzing the problem, Narrating the solution, Doing the solution, Assessing the solution and Implementing the solution). RANDAI learning model is constructed on the elements of drama and of $\mathrm{Kaba/story} \mathrm{(Arsih} \mathrm{et} \mathrm{al.,}$ 2019). Stories can improve learning memory capacity (Dahlstrom, 2014) and critical thinking (Csikar \& Stefaniak, 2018). They can also function as an effective communication tool in learning process (Giorgetti et al., 2017). Pedagogically, RANDAI learning model teaches democracy and collaboration principles through creating a circle in the show (Arsih et al., 2019).

Based on the above arguments, we assume that the RANDAI learning model has the opportunity to empower critical thinking skills. The hypothesis in this study is that the RANDAI learning model is effective in improving the critical thinking skills of biology pre-service teachers

\section{LITERATURE REVIEW}

\section{Critical Thinking Skills}

Critical thinking skills are the ability of individuals to analyze and solve problems, process data, and evaluate information so that they can generate new ideas as a form of resolution. (Kopzhassarova, Akbayeva, Eskazinova, Belgibayeva, \& Tazhikeyeva, 2016). Critical thinking involves identification, analysis and evaluation skills to draw an appropriate conclusion (Watson and Glaser, 2012).

Pre-service biology teachers need to have critical thinking skills as they are relevant to their responsibility to instill critical thinking in students (Bahr, 2010; Allammakhrah, 2012). Pre-service biology teachers who have been equipped with critical thinking skills can teach material correctly and accurately based on scientific development (Saefi, Suwono, \& Susilo, 2016) and are accustomed to self-reflection (Weissinger, 2004). Qualified teacher candidates always strive to improve the quality of their learning and in the end will produce quality graduates (Gedik, 2013).

The habituation of critical thinking skills can be done in several ways (Bahr, 2010; Farcis, 2016) as described by Radulović \& Stančić (2017), including through classroom instruction (explicit instruction), integrated with material content and mixed programs. Explicit instruction or general programming involves various learning activities that are carried out on purpose to stimulate students' critical thinking. An example of explicit instruction is a learning model developed by a teacher to improve students' thinking ability. Research by (Kuhn, 2000; Moseley et al., 2005) shows that students' critical thinking that is trained through explicit instructions embedded in a learning model or design can provide a satisfying result.

Furthermore, critical thinking can also be trained by integrating critical thinking skills indicators into the content of certain learning materials. In these programs, teachers can deliberately select learning content that can stimulate students' critical thinking. In contrast, mixed programs combine specific learning content and teaching activities. Through blended programs, teachers can implement lesson plans and instructional 
materials that help improve students' critical thinking. In mixed programs, teachers are also allowed to select materials and design learning activities sheets as a medium.

\section{RANDAI Learning Model}

RANDAI is a learning model produced from the integration of Minangkabau Randai cultural values into problem-based learning. Randai is a traditional art performance from West Sumatera. RANDAI learning model adapts the principles of problem-based learning that refer to the constructivism theory using a contextual approach. The combination of the constructivism theory, approach, and principles makes RANDAI a relevant learning model for $21^{\text {st }}$ century education. RANDAI learning model facilitates the development of pre-service biology teachers' ability to deal with contextual problems found in everyday life (Arsih, Zubaidah, Suwono, \& Gofur, 2019).

RANDAI as a cultural integrated learning model creates a learning process that serves as an exploration arena for pre-service teachers to achieve rational scientific knowledge in a particular discipline (Suastra, 2017). The integration of culture into a learning model can promote the development of learners' thinking ability and character values (Williams, 2016).

RANDAI learning model is characterized by kaba or bakaba (telling a story) and drama that is packaged in the form of stage performance. RANDAI learning model draws on the principle that problems wrapped in kaba (stories) can be used as a starting point to obtain knowledge from the materials being studied. Bakaba encourages information processing. Rehalat (2014) explains that information processing refers to the ways individuals collect or accept stimuli from the environment, solve problems, discover concepts, and use verbal symbols. Information processing is also a part of elaboration activity (Barden \& Tormala, 2014) that facilitates pre-service teachers to develop concept understanding (Duran \& Duran, 2014), acquire more information, and apply it in a real-life context (Liewellyn, 2013). Overall, the syntax of RANDAI learning model is comprised of six stages: (1) Reciting, (2) Analyzing the problem, (3) Narrating the solution, (4) Doing the solution, (5) Assessing the solution, and (6) Implementing the solution (Arsih, Zubaidah, Suwono, \& Gofur, 2019).

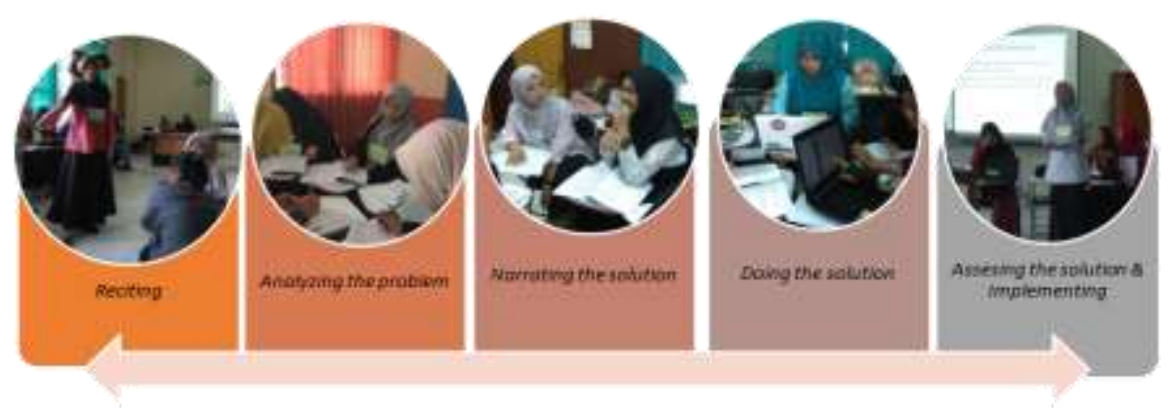

Figure 1

The scheme of the RANDAI learning model syntax 


\section{METHOD}

\section{Research Design}

This study is a quasi-experimental study using a pretest-post-test nonequivalent control group design (Cohen, Manion, \& Morrison, 2011) and involved three sample groups (experimental, positive control, negative control). RANDAI learning model was applied to the experimental class, which is the development of integrated PBL learning with Minangkabau cultural values. PBL learning was implemented in the positive control class while the negative control group was carried out without using a special learning model (conventional/direct learning). Meanwhile, critical thinking skills are the dependent variable. Table 1 . shows the design of this study

Table 1

Research design in the assessment phase

\begin{tabular}{clll}
\hline Pretest & Treatment Group & Number of students & Posttest \\
\hline $\mathrm{O}_{1}$ & RANDAI & 38 & $\mathrm{O}_{2}$ \\
\hline $\mathrm{O}_{3}$ & PBL & 33 & $\mathrm{O}_{4}$ \\
\hline $\mathrm{O}_{5}$ & Konvensional (direct learning) & 36 & $\mathrm{O}_{6}$ \\
\hline
\end{tabular}

\section{Research Samples}

This experimental research was carried out on fifth-semester students registered in the 2018/2019 academic year. It involved 107 pre-service biology teachers aged between 19-20 years old. The participants had been registered in a "Human Anatomy and Physiology" course at a university in West Sumatera, Indonesia. Homogeneity testing was performed to determine the samples. The sample class was selected randomly. The analysis of the homogeneity test result was conducted using SPSS 23.0 for Windows.

\section{Instrument}

This research is supported by learning tools in the form of lesson plans and student worksheets. The research instrument was a critical thinking essay test with as many as 15 questions and an assessment rubric. The test tool is categorized as valid with a validity value of $0.453-0.693$ and reliable with a value of $0.795-0.838$. The students' scoring of the answers given refers to the rubric. The rubric for assessing critical thinking skills refers to Finken and Ennis (2001) with the FRISCO indicator (focus, reason, conclusion, situation, clarity, and general description) modified by Zubaidah (2015) with a reliability value of 0.896 .

Data collection begins with the validation process of learning tools and instruments. This validation was carried out by five experts on biology learning and cultural integrated learning who were invited to validate the syllabus, lesson plans, worksheets, and critical thinking rubrics. The results of the validation show that the supporting learning devices are categorized as valid with respective values of $4.51,4.58,4.68$, and 4.60 .

\section{Procedures}

Each of the classes was taught using different learning models (RANDAI, PBL, and conventional). 
RANDAI learning model was implemented in the experimental class. Learning was conducted by (1) Reciting; the students introduced a problem through the performance of kaba (story), (2) Analyzing the problem; the students identified and analyzed the problem implied in the kaba (story) told by an individual student, (3) Narrating the solution; the students barudiang (discussed) the problem and designed an investigation, (4) Doing the solution; the students saliang bakarajosamo (worked cooperatively) to solve the problem, (5) Assessing the solution; every group barundiang (discussed the problem) based on bulek kato dek mufakat principle and reflected, assessed and evaluated the strengths and shortcomings of the investigation activity, (6) Implementing; the students applied the solution in their daily life. The students in this classroom conducted learning in groups and implemented the cultural values that had been integrated into the learning model.

In the positive control class, Problem-Based Learning (PBL) was applied. The stages of PBL suggested by Wood (2004) consisted of the following activities: (1) students were divided into small groups and asked to solve a problem, (2) the students decided the steps to solving the problem, (3) the students communicated the problem-solving result, (4) In the final section, the students reflected on their performance.

Meanwhile, the learning process in the conventional class was dominated by classroom discussions and question and answer sessions. The process was initiated by the teacher's presentation of the material summary. Then, guidance was provided for the students to discuss the material in groups and ask questions to other groups who were delivering group presentation. Before the end of the lesson, the teacher provided material reinforcement and formulates conclusions, in this session students listen carefully to the teacher's explanation. In this class, learning is more teacher-centered.

\section{Data analysis}

The research data were analyzed through the ANCOVA and LSD (Least Significant Difference) tests using the SPSS for windows version 22.0 application and followed by the LSD test to test the significance of these effects. However, previously the Kolmogorov-Smirnov test and Levene's test were carried out to obtain data normality and homogeneity.

\section{FINDINGS}

\section{The Results of the Normality and Homogeneity Tests of the Pre-Service Biology Teachers' Critical Thinking Scores}

The results of the prerequisite tests (normality and homogeneity tests) showed that the pre-service biology teachers' critical thinking scores were distributed normally and homogeneously (Table 2). The prerequisite test results (normality and homogeneity tests) show that the pre-service biology teacher critical thinking scores are normally distributed and homogeneous (Table 2). 
Table 2

The results of the normality and homogeneity tests of the pre-service teachers' critical thinking scores

\begin{tabular}{llll}
\hline Treatment Group & $\mathrm{N}$ & Normality & Homogeneity \\
\hline Critical thinking pretest & 107 & 0.641 & 0.159 \\
\hline Critical thinking post-test & 107 & 0.496 & 0.202 \\
\hline
\end{tabular}

The effect of RANDAI learning model on the pre-service biology teachers' critical thinking skills

Table 3. shows the results of the analysis of the application of RANDAI in improving the critical thinking skills of pre-service biology teachers

Table 3

The effect of the learning models on the participants' critical thinking skills

\begin{tabular}{llllll}
\hline Source & Type III sum of Squares & Df & Mean Square & F & Sig. \\
\hline Corrected Model & $1364.042 \mathrm{a}$ & 3 & 454.681 & 17.067 & 0.000 \\
\hline Intercept & 13128.240 & 1 & 13128.240 & 492.774 & 0.000 \\
\hline pretest & 384.791 & 1 & 384.791 & 14.443 & 0.000 \\
\hline Class & 1290.900 & 2 & 645.450 & 24.227 & 0.000 \\
\hline Error & 2744.073 & 103 & 26.641 & & \\
\hline Total & 623849.775 & 107 & & & \\
\hline Corrected Total & 4108.115 & 106 & & & \\
\hline
\end{tabular}

Table 3 contains information on the difference among the learning models implemented in the study $(F$ calculated $=24.227$ with $p$-value $=0.000 . \mathrm{P}$-value $<\alpha(\alpha=0.05)$. The figures suggest that the hypothesis "RANDAI learning model has an effect on preservice biology teachers' critical thinking skills" can be accepted. After proving the hypothesis, the LSD test was run. The test results are summarized in Table 4.

Table 4

Summary of the LSD test results based on learning models

\begin{tabular}{lllllll}
\hline Class & Pretest & $\begin{array}{l}\text { Post- } \\
\text { test }\end{array}$ & Difference & Increase $(\%)$ & $\begin{array}{l}\text { Corrected } \\
\text { Item-Total }\end{array}$ & $\begin{array}{l}\text { LSD } \\
\text { Notation }\end{array}$ \\
\hline Conventional & 52.78 & 72.41 & 19.63 & 37.19 & 71.52 & $\mathrm{a}$ \\
\hline PBL & 47.84 & 76.02 & 28.18 & 57.08 & 76.24 & $\mathrm{~b}$ \\
\hline RANDAI & 45.89 & 79.68 & 33.79 & 73.63 & 80.34 & $\mathrm{c}$ \\
\hline
\end{tabular}

The critical thinking skills of participants in the RANDAI class differed significantly from the PBL and conventional classes, which was indicated by the difference in notation between the three learning models. Table 4 also shows that there is a difference in the average corrected score between the three learning models. The RANDAI value (80.34) was higher than the PBL (76.24) and conventional (71.52) learning models. The RANDAI learning model shows better results than students who are taught using the PBL and conventional learning models. Based on these findings, the RANDAI learning model can be used as an alternative to improve the critical thinking skills of pre-service biology teachers. 


\section{DISCUSSION}

Statistical analysis showed that RANDAI learning model affected the pre-service biology teachers' critical thinking skills. The implementation of RANDAI has facilitated the improvement of the pre-service biology teachers' critical thinking skills. The posttest scores indicate that the RANDAI learning model is able to significantly increase the achievement of critical thinking values. The significant improvement of the participants' scores was affected by the syntax of RANDAI that was focused on problem-based learning while upholding the Minangkabau cultural values and principles. RANDAI learning model was also able to stimulate the participants' interest in learning, provide an opportunity for them to not only accept and imitate information (Pannen \& Sardjiyo, 2005 ) and allow them to experience more meaningful culture-integrated learning (Fadli $\&$ Irwanto, 2020). Meaningful learning can be obtained through the active involvement of pre-service teachers in constructing knowledge based on learning experience and interactions with the environment and nature surrounding them (Kanhadilok \& Watts, 2013). According to Serin (2013), education and the learning environment contribute to empowerment towards improving the critical thinking skills of pre-service teachers.

RANDAI learning model adapts the principles of Problem-Based Learning (PBL) that incorporates local culture using constructivism learning theory and contextual approach. RANDAI learning model facilitates pre-service biology teachers to practice solving contextual problems. Through RANDAI, pre-service biology teachers are actively engaged in exploring thinking skills either individually or collaboratively in groups (Arsih, Zubaidah, Suwono, \& Gofur, 2019)

Bakaba helps pre-service teachers creatively use imagination, discuss stories, and make the knowledge appealing (Giorgetti, Campbell, \& Arslan, 2017). Hardiman et al. (2019) also stated that the cultural values embedded in learning instructions contribute to strengthening academic concepts and making them more interesting. There is a positive correlation between the integration of multicultural content into learning and student achievement, motivation, self-efficacy, creativity, critical thinking, collaboration, and engagement in biology learning. In line with past studies, this meta-analysis provides support for the possibility that the integration of art and culture in improving student achievement in the cognitive domain, including in problem-solving and critical thinking. Research has also indicated that the integration of art and culture into learning can serve as a tool to bridge the gap between the underachievers and high-achievers in the classroom.

The second syntax of RANDAI is Analyzing the problem. The activities performed at this stage include identifying and analyzing problems as a means to stimulate critical thinking. Pre-service biology teachers will become independent and critical when they are trained to analyze, evaluate, and synthesize information from various sources and present the information according to their own interpretation (El-Shaer \& Gaber, 2014). The exploration of information to identify problems contributes positively to the development of students' critical thinking (Bassham et al. 2011). When pre-service teachers struggle to find and discuss problems to solve a task, they are building the procedural and conceptual understanding of a concept (King, 2019). 
The third syntax of RANDAI is narrating and executing the solution, where the preservice biology teachers in this study performed a barundiang (discussion) activity based on saliang bakarajo samo (collaboration) principles in designing an investigation. This syntax is known to stimulate the discovery and investigation processes that can empower students to think critically. Through barundiang activity, the pre-service biology teachers interacted with each other to apply the cultural values of duduak basamo balapang-lapang (sit together), barundiang (discussion) and bakarajosamo (collaboration). In groups, the pre-service biology barundiang (discussed) ideas on the problem solution. Every individual was allowed to deliver their thoughts and explain the result of the analysis conducted in the previous stage. This syntax is in line with Gagne, 1980 (Temel, 2014), who states that education primarily aims to teach individuals how to think and solve problems effectively so that they can contemplate, research, and produce solutions to the problems they face in real life.

Assessing the solution is the last stage in RANDAI that allows pre-service teachers to communicate the investigation results as well as to reflect and evaluate the strengths and weaknesses of the whole investigation process. Assessing the solution aims to provide feedback to the entire problem-solving process. This activity is based on the opinion of Moreno (2010), who mentions that student involvement in reflection and evaluation provides an opportunity for them to promote the ability to analyze, criticize, and draw a conclusion which results indirectly in their critical thinking development.

The discrepancy in the critical thinking scores between RANDAI, PBL, and conventional classes was also caused by the different learning environments that influenced the participants' motivation in learning. The relaxed learning atmosphere in RANDAI due to the performance of kaba (stories) was able to motivate the students. Motivation plays an important role in the classroom, students who have excellent learning orientation or high motivation will be able to easily achieve higher-order thinking (Suwono \& Dewi, 2019).

The results of this study are corroborated with the findings of Anazifa (2016), who explains that Problem-Based Learning can affect students' critical thinking skills. The integration of culture into PBL contributes to the development of students' critical thinking. Saragih, Napitupulu, \& Fauzi (2017) have reported the effectiveness of the integration of local culture and student-centered learning in improving students' thinking ability. Another study has also proven that culture-integrated PBL can improve student academic achievement. Also, Arwita et al. (2017) found that integrating the social interaction system of Dalihan Na Tolu into PBL able increase student achievement. Besides, research by Parwati et al. (2018) also shows that learning models that are oriented to local wisdom are effective in improving student problem-solving skills as an indicator of critical thinking. The learning culture that incorporates local wisdom has a significant effect on students' ability to solve problems (Fadli \& Irwanto, 2020), which constitutes part of critical thinking skills. On the one hand, the findings of this study are relevant to the previous research in terms of supporting the development of the $21^{\text {st }}$ century skills. On the other hand, RANDAI learning model enables pre-service teachers to prevent Minangkabau culture from being washed away due to globalization. 
Therefore the RANDAI learning model can function as a strategy in preserving culture and enhancing the critical thinking skills of pre-service biology teachers.

This study was limited to a particular variables and subjects at the higher education level. In order to more measure the effectiveness of the Randai model, further study can be carried out by implementing the RANDAI model in other courses and at the high school level.

\section{CONCLUSIONS}

The findings showed that the RANDAI learning model had a more significant effect on the critical thinking skills of pre-service biology teachers in improving critical thinking with an average score of 80.34 . Thus it can be concluded that the thinking ability of preservice biology teachers can be empowered through the RANDAI model.

\section{ACKNOWLEDGMENTS}

The authors would like to acknowledge the Indonesian Ministry of Research, Technology and Higher Education for the sponsorship provided under a contract number No.10.3.49/UN32.14/LT/2020

\section{REFERENCES}

Abed, O. H. (2016). Drama-Based Science Teaching and Its Effect on Students' Understanding of Scientific Concepts and Their Attitudes towards Science Learning. International Education Studies, 9(10), 163-173. doi:10.5539/ies.v9n10p163

Akben, N. (2019). Suitability of Problem Scenarios Developed by Pre-service Teacher Candidates to Problem-Based Learning Approach. Eurasian Journal of Educational Research, 83(2019), 231-252. doi: 10.14689/ejer.2019.83.11

Allamnakhrah, A. (2013). Learning Critical Thinking in Saudi Arabia: Student Perceptions of Secondary Pre-Service Teacher Education Programs. Journal of Education and Learning, 2(1), 197-210. doi:10.5539/jel.v2n1p197

Alkharusi, H. A., Sulaimani, H. A., \& Neisler, O. (2019). Predicting Critical Thinking Ability of Sultan Qaboos University Students. International Journal of Instruction, 12(2), 491-504. Retrieved from https://doi.org/10.29333/iji.2019.12231a

Al-Mahrooqi, R., \& Denman, C. J. (2020). Assessing Students' Critical Thinking Skills in the Humanities and Sciences Colleges of a Middle Eastern University. International Journal of Instruction, 13(1), 783-796. Retrieved from https://doi.org/10.29333/iji.2020.13150a

Amin, A. M., Zubaidah, S., Corebima, A. D., \& Mahanal, S. (2017). The Critical Thinking Skills Profile of Preservice Biology Teachers in Animal. 3rd International Conference on Education and Training (ICET, 2017). 128, pp. 179-183. Atlantis Press. http://creativecommons.org/licenses/by-nc/4.0/

Anazifa, R. D. (2016). The Effect of Problem- Based Learning on Critical Thinking Skills and Student Achievement. 3rd International Conference on Research, Implementation, and Education of Mathematics and Science (pp. BE43-BE48). Yogyakarta. 
Anwar, Suardika, I. K., T, M., Suleiman, A. R., \& Syukur, M. (2018). Kalosara Revitalization as an Ethno-Pedagogical Media in the Development of Character of Junior High School Students. International Education Stud, 11(1), 172-183. doi:10.5539/ies.v11n1p172

Arsih, F., Zubaidah, S., Suwono, H., \& Gofur, A. (2019). The Exploration of Educational Value in Randai Minangkabau Art, Indonesia. Journal for the Education of Gifted Young Scientists, 7(4), 1225-1248. doi:10.17478/jegys.605463

Arsih, F., Zubaidah, S., Suwono, H., \& Gofur, A. (2020). Critical thinking skills of prospective biology teachers: A preliminary analysis. The 3rd International Conference on Mathematics and Sciences Education (ICoMSE) (pp. 030001-1-7). Malang: AIP Publishing. doi:10.1063/5.0000538

Arwita, W., Amin, M., Susilo, H., \& Zubaidah, S. (2017). Integrating the Social Interaction System of Dalihan Na Tolu inti the Problem Based Learning on BIology Subjects to Increase Students Achievement. International Journal of Science and Research (IJSR), 1-5.

Badger, J. (2019). A Case Study of Chinese Students" and IEP Faculty Perceptions of a Creativity and Critical Thinking Course. Higher Education Studies, 9(3), 34-44. doi:10.5539/hes.v9n3p34

Bahr, N. (2010). Thinking Critically aboaut Critical Thinking in Higher Education. International Journal for the Scholarship of Teaching and Learning, 4(2), 1-14. doi:10.20429/ijsotl.2010.040209

Batdi, V. (2014). The effects of a problem based learning approach on students' attitude levels: A meta-analysis. Educational Research and Reviews, 9(9), 276-279. doi: 10.5897/ERR2014.1771.

Barden, J., \& Tormala, Z. L. (2014). Elaboration and Attitute Stength: The New Metacognitive Perspektive. Social and Personality Psychology, 8(1), 17-29.

Barrett, T. (2013). Learning About the Problem in Problem-Based Learning (PBL) by Listening to Students' Talk In Tutorials: A Critical Discourse Analysis Study. Journal of Further and Higher Education, 37(4), 519-535. doi:10.1080/0309877X.2011.645464

Birgili, B. (2015). Creative and Critical Thinking Skills in Problem-based Learning Environments. Journal of Gifted Education and Creativity, 2(2), 71-80. doi:10.18200/JGEDC.2015214253

Caballero, J. (2015, Oktober, 25). The Importance of Culture-Based Education. Retrieved from http://jan.ucc.nau.edu/.pdf

Cohen, L., Manion L., \& Morrison, K. (2011). Research Methods in Education 7th edition. New York: Routledge.

Csikar, E., \& Stefaniak, J. E. (2018). The Utility of Storytelling Strategies in the Biology Classroom. Contemporary Education Technology, 9(1), 42-60. 
Cretu, D. (2017). Fostering 21st Century Skill for Future Teachers. The European Proceedings of Social \& Behavioural Sciences: Edu World 2016 7th International Conference (pp. 1-11). Futura Academy. https://www.futureacademy.org.uk

Dahlstrom, M. F. (2014). Using narratives and storytelling to communicate science with nonexpert audiences. Proceeding of National Academy of Science of The United States of America, 111(4). doi:10.1073/pnas.1320645111

Davison, D. M., \& Miller, K. W. (1998). An Ethnoscience Approach to Curriculum Issues for American Indian Students. School Science and Mathematics, 98(5), 260-265. doi:10.1111/j.1949-8594.1998.tb17299.x

Demircioğlu, H., Dinç, M., \& Çalik, M. (2013). The Effect of Storylines Embedded Within Context-based Learning Approach On Grade 6 Students' Understanding of 'Physical And Chemical Change' Concept. Journal of Baltic Science Education, 12(5), 682-691. http://www.scientiasocialis.lt

Demirel, M., \& Dağyar, M. (2016). Effects of problem-based learning on attitude: A meta-analysis study. Eurasia Journal of Mathematics, Science and Technology Education, 12(8), 2115-2137 doi: 10.12973/eurasia.2016.1293a

Duran, L., \& Duran, E. (2014). The 5E Instructional Model: A Learning Cycle Approach for Inquiry-based Science Teaching. The Science Education Review, 3(2), 49-58.

Evens, M., Verburgh, A., \& Elen, J. (2014). The Development of Critical Thinking in Profesional and Academic Bachelor Programmes. Higher Education Studies, 4(2), 42 51. doi:10.5539/hes.v4n2p42

El-Shaer, A., \& Gaber, H. (2014). Impact of Problem-Based Learning on Students'Critical Thinking Dispositions, Knowledge Acquisition, and Retention. Journal of Education and Practice, 5(14), 74-87. http://iiste.org/Journals/index.php/JEP

Fadli, A., \& Irwanto. (2020). The Effect of Local Wisdom-Based ELSII Learning Model on the Problem Solving and Communication Skills of Pre-Service Islamic Teachers. International Journal of Instruction, 13(1), 731-746. doi:10.29333/iji.2020.13147a

Farcis, F. (2016). Practicing Critical Thinking Skills Through Study Journal. International Research Clinic \& Scientific Publications of Educational Technology (pp. 458-480).

Facione, P. (2011). Critical Thinking: What It is and Why It Count. Millbrae: Measured Reason and the California Academic Press.

Fitriani, H., Asy'ari, M., Zubaidah, S., \& Mahanal, S. (2019). Exploring the Prospective Teachers' Critical Thinking and Critical Analysis. Jurnal Pendidikan IPA Indonesia, 8(3), 379-390. doi:10.15294/jpii.v8i3.19434

Fuad, N. M., Zubaidah, S., Mahanal, S., \& Suarsini, E. (2017). Improving Junior High Schools' Critical Thinking Skills Based on Test Three Different Models of Learning. International Journal of Instruction, 10(1), 101-116. doi:10.12973/iji.2017.1017a 
Gedik, H., 2013. Social Studies Teacher Candidates' Critical Thinking Skills. Procedia Social and Behavioral Sciences, 93(2013): 1020-1024.

Giorgetti, F. M., Campbell, C., \& Arslan, A. (2017). Culture and education: looking back to culture. Paedagogica Historica: International Journal of the History of Education, 1-6. doi:10.1080/00309230.2017.1288752

Hardiman, M. M., JohnBull, R. M., Carran, D. T., \& Shelton, A. (2019). The effects of arts-integrated instruction on memory for science content. Trends in Neuroscience and Education, 14, 25-32. doi:10.1016/j.tine.2019.02.002

Halpern, D. F. (1999). Teaching for Critical Thinking: Helping College Students Develop the Skills and Dispositions of a Critical Thinker. In Teaching and Learning on The Millennium. Jossey-Bass Publishers.

Hidayati, N., Zubaidah, S., Suarsini, E., \& Praherdhiono, H. (2019). The Integrated PBL-DMM: A Learning Model to Enhance Student Creativity. Pedagogika, 135(3), 163-184. doi:10.15823/p.2019.135.9

Ibe, E. (2017). Effects of Ethnoscience and Traditional Laboratory Practical on Science Process Skills Acquisition of Secondary School Biology Students in Nigeria. British Journal of Multidisciplinary and Advanced Studies, 35-46.

James, K. (2006). Identify cultural values and American Indians Perceptions of Science and technology. American Indian Culture and Research Journal, 45-55.

Kadir, M. A. (2017). What Teacher Knowledge Matters in Effectively Developing Critical Thinkers in the 21 st Century Curriculum? Thinking Skills and Creativity, 23(2017), 79-90. doi:10.1016/j.tsc.2016.10.011

King, B. (2019). Using Teaching Through Problem Solving to Transform In-Service Teachers' Thinking about Instruction. Mathematics Teacher Education and Development, 1, 169 -189. https://files.eric.ed.

Kopzhassarova, U., Akbayeva, G., Eskazinova, Z., Belgibayeva, G., \& Tazhikeyeva, A. (2016). Enhancement of Students Independent Learning Through Their Critical Thinking Skills Development. International Journal of Environmental \& Science Education, 11(18), 11585-11592.

Kuhn, D. (2000). Metacognitive Development. Current Directions in Psychological Science, 9, 178-181. http://0-search.ebscohost.com.library.alliant.edu

Liewellyn, D. (2013). Teaching High School Science through Inquiry and Argumentation. United State of America: Corwin Press.

Madelo, N. Q. (2015). The Influence of spirituality of Teachers and Moral Values of Students on the 21 st century skills development of students. International Journal of Novel Research in Education and Learning, 2(4), 22-61. http://www.noveltyjournals.com/

Marin, L. M., \& Halpern, D. F. (2011). Pedagogy for developing critical thinking in adolescents: Explicit instruction produces greatest gains. Thinking Skills and Creativity, 6(2011), 1-13. doi:10.1016/j.tsc.2010.08.002 
Moseley, D., Elliott, J., Gregson, M., \& Higgins, S. (2005). Thinking skills frameworks for use in education and training. British Educational Research Journal, 31(3), 367-390. doi:10.1080/01411920500082219

Moreno, R. (2010). Education Pschology. New York: John Wiley \& Sons Inc.

Moutinho, S., Torres, J., Fernandes, I., \& Vasconcelos, C. (2015). Problem-Based Learning and Nature of Science: A Study With Science Teachers. Procedia - Social and Behavioral Sciences, 191, 1871 - 1875. doi: 10.1016/j.sbspro.2015.04.324

Nessipbayeva, O. (2012). The Competencies of the Modern Teacher. https://files.eric.ed.gov/fulltext/ED567059.pdf

Nijhuis, J., Gijselaers, W., \& Segers, M. R. (2005). Influence of Redesigning a Learning Environment on Student Perceptions and Learning Strategies. Learning Environments Research(8), 67-93. doi:10.1007/s10984-005-7950-3

Parwati, N. N., Sudiarta, I. G., Mariawan, I. M., \& Widiana, I. W. (2018). Local Wisdom-oriented Problem-Solving Learning Model to Improve Mathematical ProblemSolving Ability. Journal of Technology and Science Education, 8(4). http://www.jotse.org/index.php/jotse/article/view/401/336

Radulović, L., \& Stančić, M. (2017). What is Needed to Develop Critical Thinking in Schools? Center for Educational Policy Studies Journal, 9-25. https://files.eric.ed.gov/fulltext/EJ1156618.pdf

Saefi, M., Suwono, H., \& Susilo, H. (2016). Biology Student Teacher's Critical Thinking: An Exploration Study. International Conference on Education (pp. 605-613). Malang: Graduate School, Universitas Negeri Malang.

Saragih, S., Napitupulu, E. E., \& Fauzi, F. (2017). Developing Learning Model Based on Local Culture and Instrument for Mathematical Higher Order Thinking Ability. International Education Studies, 10(6), 114-122. doi:10.5539/ies.v10n6p114

Serin, O. (2013). The Critical Thinking Skills of Teacher Candidates Turkish Republic of Northern Cyprus Sampling. Eurasian Journal of Educational Research, 53, 231-248.

Suardana, I. N., Redhana, I. W., Sudiatmika, A. A., \& Selamat, I. N. (2018). Students' Critical Thinking Skills in Chemistry Learning Using Local Culture-Based 7E Learning Cycle Model. International Journal of Instruction, 11(2), 399-412. doi:10.12973/iji.2018.11227a

Suastra, I. W. (2017). Balinese Local Wisdoms and their Implications in Science Education at School. International Research Journal of Management, IT \& Social Sciences, 4(2), 42-50. doi:10.21744/irjmis.v4i2.389

Suwono, H., Pratiwi, H. E., Susanto, H., \& Susilo, H. (2017). Enhancement of students' biological literacy and critical thinking of biology through socio-biological case-based learning. Jurnal Pendidikan IPA Indonesia, 6(2), 213-220. doi: 10.15294/jpii.v6i2.9622

Suwono, H., \& Dewi, E. K. (2019). Problem-Based Learning Blended with Online Interaction to Improve Motivation, Scientific Communication and Higher Order 
Thinking Skills of High School Students. International Conference for Science Educators and Teachers (ISET) (pp. 1-9). Bangkok, Thailand: AIP Publishing.

Syam, M., \& Efwinda, S. (2018). Analisis Keterampilan Berpikir Tingkat Tinggi Dengan Menerapkan Model Problem Based Learning (PBL) Pada Mata Kuliah Fisika Dasar di FKIP Universitas Mulawarman [Analysis of Higher-Order Thinking Skills by Applying Problem Based Learning (PBL) Models to Basic Physics Subjects at FKIP Mulawarman University]. Seminar Nasional Fisika. Makasar. http://ojs.unm.ac.id/semnasfisika/article/view/8695/5067

Temel, S. (2014). The effects of Problem Based Learning on Pre-service Teachers' Critical Thingking Disposition and Persepsion of Problem Solving Ability. South African Journal of Education, 34(1), 1-20.

Uge, S., Neolaka, A., \& Yasin, M. (2019). Development of Social Studies Learning Model Based on Local Wisdom in Improving Students' Knowledge and Social Attitude. International Journal of Instruction, 12(3), 375-388. doi:10.29333/iji.2019.12323a

Valli, L., \& Buese, D. (2007). The Changing Roles of Teachers in an Era of HighStakes Accountability. American Educational Research Journal, 44(3), 519-558. doi:10.3102/0002831207306859

Valli, P., Perkkilä, P., \& Valli, R. (2014). Adult Pre-Service Teachers Applying 21st Century Skills in the Practice. Athens Journal of Education, 1(2), 115-129. https://www.atiner.gr/journals/education

Watson, G., \& Glaser, E. M. (2012). Watson-Glaser ${ }^{\mathrm{TM}}$ Critical Thinking Appraisal User-Guide and Technical Manual. United States of America: Pearson Education Ltd.

Weissinger, P.A. (2004). Critical Thinking, Meta-cognition, and Problem-Based Learning. In Enhancing Thinking through Problem Based Learning Approach: International Perspectives, O.S.Tan (Ed.). Singapore: Thomson.

Williams, J. (2016). Art Education with Attitude. Journal of Social Science Education, 15(4), 7-14. doi:10.2390/jsse-v15-i4-1491

Wood, D. F. (2007). ABC of learning and teaching in medicine: Problem based learning. doi:10.1136/bmj.326.7384.328

Zubaidah, S. (2017). Pembelajaran Kontekstual Berbasis Pemecahan Masalah Untuk Mengembangkan Kemampuan Berpikir Kritis [Problem Solving Based Contextual Learning To Develop Critical Thinking Abilities]. Seminar Nasional dengan Tema Mengimplementasikan Pendidikan Berwawasan Konservasi dalam Mewujudkan Sumber Daya Manusia yang Berkarakter, (hal. 1-17). Makasar.

Zubaidah, S., Corebima, A. D., \& Mistianah. (2015). Asesmen Berpikir Kritis Terintegrasi Tes Essay [Integrated Critical Thinking Assessment Essay Test]. Symposium on Biology Education, (hal. 200-213).

Zubaidah, S., Corebima, A. D., Mahanal, S., \& Mistianah. (2018). Revealing the Relationship between Reading Interest and Critical Thinking Skills through Remap GI and Remap Jigsaw. International Journal of Instruction, 11(2), 41-56. Retrieved from https://doi.org/10.12973/iji.2018.1124a. 